
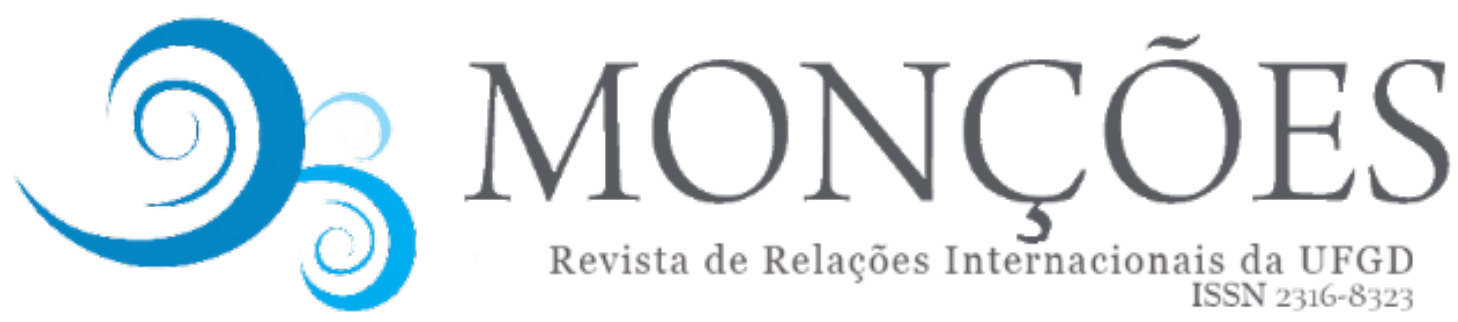

Revista de Relações Internacionais da UFGD

ISSN 2316-8323

\title{
INTERVENÇÕES HUMANITÁRIAS E TEORIA CRÍTICA NO BRASIL: INIBIÇÕES E ALTERNATIVAS RADICAIS AO PARADIGMA DA PAZ LIBERAL
}

MIGUEL BORBA DE SÁ 1

Professor Doutor da Universidade Federal de Santa Catarina

\begin{abstract}
RESUMO: A baixa penetração no Brasil de teorias críticas ao intervencionismo humanitário reflete-se na escassez de trabalhos acadêmicos capazes de questionar frontalmente a Missão das Nações Unidas para Estabilização do Haiti (Minustah). Este artigo busca suprir parcialmente estas lacunas mediante a apresentação de ferramentas teóricas disponíveis alhures, em paralelo às observações feitas durante trabalho de campo no Haiti. O objetivo é romper as inibições quanto às objeções radicais à chamada Paz Liberal de modo a abrir caminho para uma teorização crítica brasileira que possa ir além daquela já disponível no mundo acadêmico anglo-saxão.
\end{abstract}

PALAVRAS-CHAVE: intervenções humanitárias; Minustah; Teoria Crítica.

\section{HUMANITARIAN INTERVENTION AND CRITICAL THEORY IN BRAZIL: INHIBITIONS AND RADICAL ALTERNATIVES TO THE LIBERAL PEACE PARADIGM}

\begin{abstract}
The low penetration in Brazil of critical theories regarding humanitarian interventionism reflects itself in the scarcity of academic works able to put into question the United Nations Mission for the Stabilization of Haiti (Minustah). This article aims at filling part of those gaps by presenting a range of theoretical tools available elsewhere, in parallel to observations made during field-work done in Haiti. The objective is to overcome the inhibitions that radical objections to the so-called Liberal Peace currently face so as to open a path for a Brazilian critical theorizing that might go beyond the ones already available at the Anglo-Saxon academic world.
\end{abstract}

KEYWORDS: Humanitarian interventions; Minustah; Critical Theory.

\section{Introdução}

A teorização crítica em Relações Internacionais (RI) no âmbito acadêmico brasileiro vem crescendo consideravelmente nos últimos anos, em concomitância à proliferação de departamentos e institutos de pesquisa centrados no estudo da política internacional neste país. No entanto, naquilo que se refere às chamadas

${ }^{1}$ Professor Substituto no Departamento de Economia e Relações Internacionais da Universidade Federal de Santa Catarina e membro do Laboratório Interdisciplinar de Estudos em Relações Internacionais da Universidade Federal Rural do Rio de Janeiro. 
intervenções humanitárias, chama a atenção a baixa quantidade de trabalhos críticos dedicados ao tema. Com efeito, é difícil encontrar artigos ou livros que atendam a dois critérios elementares das Teorias Críticas, conforme a conhecida formulação feita por Robert Cox (1981): que ousem (i) fazer uma abordagem sem concessões aos paradigmas e estruturas de poder dominantes, tanto do ponto de vista teórico, quanto normativo; e que (ii), como consequência, evitem ser Teorias de Resolução de Problemas, ou seja, aquelas que abordam aspectos parciais de uma dada totalidade no sentido de aperfeiçoá-la sem, contudo, engajar-se num processo de transformação (ou rejeição) radical do status quo, que termina, assim, reforçado (HEATHERSHAW, 2008, p.602). ${ }^{2}$

Esta inibição na teorização crítica reflete-se no tipo de abordagem acadêmica disponível sobre a Missão das Nações Unidas para Estabilização do Haiti (Minustah). Apesar de estarem surgindo reportagens com denúncias sobre a conduta das tropas lideradas pelo Brasil durante toda a missão (2004-2017), faltam instrumentos teóricos capazes de guiar este escrutínio mais apurado que ora se inicia. ${ }^{3}$ Diante deste quadro, o presente artigo pretende contribuir para supressão destas lacunas de duas formas. Em primeiro lugar, apresentando ao público brasileiro uma série de abordagens feitas a partir de Teorias Críticas ao intervencionismo humanitário, considerado a pedra angular do regime de governança global que os críticos classificam como o "projeto da Paz Liberal" (PUGH, 2005, p. 23). Em segundo lugar, permeando tais abordagens com as poucas reflexões baseadas em Teorias Críticas feitas sobre a última intervenção multilateral no Haiti, além de trazer exemplos, dados e relatos que as respaldem. Tais informações foram colhidas em trabalho de campo realizado pelo autor deste artigo no último ano da Missão, mas sem qualquer vínculo com a mesma, beneficiando-se apenas da acolhida proporcionada por movimentos sociais naquele país. 4 ${ }^{2}$ Por outro lado, objeções de caráter realista e neorrealista às intervenções humanitárias obtiveram
maior espaço, geralmente apontando a seletividade de tais operações e sua serventia a algum
interesse nacional, i.e., egoísta, de fundo. Para um bom apanhado da crítica realista sobre o tema,
ver Mason e Wheeler (1996).
${ }^{3}$ Não surpreende, portanto, que este renovado interesse tenha fecundado mais por vias jornalísticas
do que propriamente acadêmicas, até o momento. Ver, por exemplo, reportagem da Revista Piauí, de
agosto de 2019: https://piaui.folha.uol.com.br/materia/terra-desolada/ (Acessado em Agosto de 2019).
"Desde 2010, quando ingressou na Rede Jubileu Sul Américas, o autor deste artigo fez parte de
campanhas pela retirada das tropas estrangeiras do Haiti, promovendo atividades direcionadas a 
Antes de iniciar esta apreciação da literatura crítica à Paz Liberal cotejada com elementos da intervenção no Haiti, é preciso situar brevemente, na seção seguinte, o discurso hegemônico sobre a atuação brasileira nesta operação, assim como o tipo de crítica moderada que tem sido feita ao paradigma dominante, a fim de melhor diferenciá-lo das abordagens feitas a partir de Teorias Críticas, que serão abordadas em seguida. Em outras palavras, separar as Teorias de Resolução de Problemas sobre as intervenções humanitárias das teorizações de matriz gramsciana, foucaultiana, pós-colonial ou feminista que buscam desafiar frontalmente a agenda intervencionista. O objetivo final não é, naturalmente, fazer a exegese de uma ou outra forma de teorização crítica em particular. Menos ainda sugerir que se deva simplesmente importar aquilo que já vem sendo produzido alhures, como se isto bastasse para suprir a carência de produção teórica brasileira sobre o tema em questão. Pelo contrário, a ideia é justamente partir daquilo que já existe, mas que não é suficiente, posto que proveniente do mundo acadêmico angloamericano, em direção a uma teorização crítica que vá mais além do que aquela atualmente disponível por lá. Em outras palavras, como será apontado na conclusão, desenvolver abordagens críticas à Paz Liberal a partir de saberes que só podem ser construídos desde a experiência histórica e intelectual brasileira, em particular, ou latino-americana, em geral. $\mathrm{O}$ aprofundamento desta postura contrahegemônica excede o escopo deste artigo, que se contentará em indicar seu exequibilidade teórica e prática.

\section{Brazilian way of peacekeeping e as Teorias de Resolução de Problemas}

Não apenas na academia brasileira, mas também em declarações, documentos e entrevistas de autoridades estatais, além das organizações nãogovernamentais (ONGs) que trabalharam junto com as forças militares de

impactar a opinião pública e os governos envolvidos na intervenção. Este vínculo político proporcionou uma recepção amistosa por parte de movimentos sociais haitianos (assim como da Brigada Dessalines, do Movimento dos Trabalhadores Rurais Sem Terra - MST), que ofereceram hospedagem solidária e uma série de contatos com lideranças sociais e intelectuais haitianas. Em especial, registra-se o apoio recebido pela Plataforma Haitiana de Advocacia por um Desenvolvimento Alternativo (PAPDA). Em visita ao Campo Delta da Minustah para realização de entrevistas, o force commander brasileiro Ajax Porto Pinheiro convidou o autor a se hospedar na base militar, o que foi declinado. As despesas da passagem foram cobertas pela PUC-Rio. 
pacificação, é frequente uma postura favorável ao "jeito brasileiro" (ou "modelo brasileiro") de praticar operações de paz (ABDENUR E CALL, 2017; BRAGA, 2017; CARVALHO, 2017; CLAUHS, 2013; KENKEL, 2011, p. 28-30; VIEIRA NETO, 2017). Tal literatura sustenta que "traços culturais" em comum transformam-se em "capacidades" aumentadas, que garantem maior eficácia para "estabilizar" locais como o Haiti: a pacificação brasileira seria "mais humana, progressista e responsável" (KALIL E NAPOLEÃO, 2015, p. 90; 109). Os militares do Brasil teriam uma "relação de confiança e contato direto com a população local", mostrando "humildade", sem "intimidação", estimulando o "contato com lideranças comunitárias civis da região" e "promovendo também atividades esportivas e culturais" (SOUZA NETO, 2012, p. 250-252). Defende-se, ademais, que o "soft power brasileiro" é resultado da "proximidade cultural e da identificação que muitas vezes ocorre entre o povo haitiano e os 'capacetes azuis' brasileiros", levando a uma maior eficiência "ao utilizar-se da influência cultural para assegurar o cumprimento das metas da MINUSTAH" (VIANA, 2009, p. 32-34; KAWAGUTI, 2006). Há quem defenda que o soldado brasileiro "é criativo e bem-humorado", capaz de desempenhar um "exercício de diplomacia cultural: ele reforça laços de camaradagem, ele reafirma um soft power sem pretensões impositivas, ele facilita o diálogo e a compreensão" (CARVALHO, 2017, p. 48). Todos convergem no sentido de concluir que "sem sombra de dúvida, o Brasil no Haiti é um caso de sucesso" (MENDONÇA, 2017, p. 65 - negritos no original).

Argumenta-se, ademais, que a participação do Brasil ajuda a aperfeiçoar as intervenções da Paz Liberal, na medida em que sua presença contrabalançaria a dominação das potências ocidentais, desenvolveria conhecimentos novos para a segurança internacional (como os princípios de Responsabilidade Ao Proteger e da Não-Indiferença), além de reforçar o elo entre segurança e desenvolvimento (ABDENUR E CALL, 2017; CEZNE E HAMMAN, 2016; KENKEL, 2011; LULA DA SILVA, 2014; NASSER, 2012). Neste sentido, "as características e as representações simbólicas da presença brasileira se traduziriam por um comportamento mais ameno", fundamental para "o êxito da missão" (VALLER FILHO, 2007, p. 171). E tal combinação entre uso moderado da força, foco no desenvolvimento econômico e exportação de políticas sociais bem-sucedidas 
domesticamente fariam do "modelo brasileiro de pacificação" algo replicável para além do caso do Haiti (KENKEL, 2011, p. 28-30).

Ainda nesta linha, houve quem defendesse o papel do Brasil na Minustah como exemplo das benesses de um novo modelo de "ingerência solidária" (SEITENFUS, 2006, p.7), "diplomacia solidária" (LULA DA SILVA, 2014) ou "cooperação sustentável" entre países do sul global (HIRST, 2012, p. 20). A missão teria sido um exemplo de como o Brasil utiliza a cooperação técnica como instrumento de solidariedade (VALLER FILHO, 2007) e seria indicativa dos "avanços" vinculados à "presença latino-americana na qual se destacava o Brasil", marcada pela "diferenciação" frente aos demais atores da Comunidade Internacional presentes no Haiti (HIRST, 2012, p. 20-23). De fato, tornou-se um lugar comum afirmar que "o envolvimento brasileiro merece destaque por adotar uma postura diferente" (SOUZA NETO, 2012, p. 259). Chegou-se ao ponto de propor que o chamado "Brazilian way of peacekeeping" (MENDONÇA, 2017, p. 61) se constituiria em um novo paradigma, podendo ser chamado até mesmo de "Pax Brasiliensis" devido a sua singularidade e capacidade de colocar a "solidariedade" e o "humanismo" como interesses nacionais da política externa brasileira (NASSER, 2012, p. 213).

Foi frequente o uso de argumentos raciais para embasar tais discursos sobre o êxito brasileiro na Minustah. A diplomacia ressaltou "afinidades de natureza cultural e étnica" entre Brasil e Haiti (AMORIM, 2006, p. 2) e a intelectualidade militar enfatizou a "descendência africana do Haiti, com a consequente origem comum escravocrata do povo haitiano e do soldado brasileiro" (MENDONÇA, 2017, p. 61), chegando ao ponto de defender que a "formação multiétnica" dos militares do Brasil facilitava a "liderança brasileira em missões de paz" (CLAUHS, 2013, p. 99). Houve, por fim, quem sustentasse a existência de uma maior adaptabilidade psíquica e biológica dos combatentes brasileiros, cujos organismos produziriam maiores quantidades de "hormônio antiestresse" durante a intervenção, devido à "familiaridade com situações de pobreza e miséria, semelhantes à realidade brasileira" (SOUZA NETO, 2012, p. 255).

Frente a este arsenal de manifestações autocongratulatórias, foi tarefa difícil encontrar ouvidos receptivos para vozes dissonantes. Uma causa adicional para esta dificuldade, que também é seu efeito, como sugerido na introdução, foi a baixa 
penetração de Teorias Críticas à Paz Liberal no universo acadêmico de Relações Internacionais no Brasil. Quando muito, repetiu-se entre nós o conhecido movimento circular de domesticação da crítica percebido por John Heatehrshaw (2008) ao analisar a trajetória intelectual de autores como Roland Paris (2000; 2010), quem, em menos de uma década, passou de pioneiro na teorização crítica sobre o intervencionismo ocidental a ferrenho defensor da manutenção deste mesmo paradigma. A famosa guinada teórico-normativa de Paris (2010) destinada a "salvar" a construção liberal da paz de "hipercríticas", em sua visão exageradas, é paradigmática deste duplo-movimento de estimular e conter os limites da crítica sem, contudo, abdicar das práticas intervencionistas em momento algum: "não existe alternativa realista a alguma forma liberal de estratégia de construção da paz" (PARIS, 2010, p. 338-340 - itálicos no original).

Esta dinâmica segue presente desde então, produzindo sucessivas rodadas de (auto)críticas moderadas e reformulações das doutrinas e protocolos de intervenção, sempre em busca de aperfeiçoamento operacional e - isto é crucial jamais abrindo a possibilidade de um questionamento das práticas intervencionistas como um todo. Na década atual, o conceito de Paz Híbrida (MAC GINTY, 2011; MITCHELL E RICHMOND, 2012) desempenhou este papel, apresentando-se como um substituto à Paz Liberal e simultaneamente como uma forma de prosseguir com as missões (ANAM, 2015; GOMES, 2013). Exemplarmente, após alguns anos, seus próprios proponentes mais destacados passaram a criticar os usos que estavam sendo feitos, apontando a tentativa de construir ordens políticas híbridas como uma "falácia" (MAC GINTY E RICHMOND, 2015, p.1). Desnecessário dizer que seguiram defendendo a necessidade de intervenções, agora novamente aperfeiçoadas pela distinção entre "hibridismo negativo" e "hibridismo positivo" na relação entre o local e o internacional (2015, p. 15). A mais recente rodada destas Teorias de Resolução de Problemas voltadas para o intervencionismo humanitário começa a girar em torno do conceito de Paz Adaptativa (CONING, 2018), candidato a substituir a Paz Híbrida a fim de que se continue a repaginar a Paz Liberal indefinidamente, sem jamais abandonar suas características centrais, sejam as teórico-normativas ou as de cunho bélico. Um passo a mais na chamada "virada local" (FACHINI E TOLEDO, 2017, p. 155), que não promete mudanças significativas neste repetitivo e limitado ciclo. 
Foi neste limite político e metodológico que a teorização brasileira sobre o tema esbarrou, sem que se pudesse avançar decididamente em nenhuma crítica mais radical (no sentido de ir à raiz dos problemas). Por exemplo, Toledo e Facchini (2017), fazem uma apreciação sutilmente favorável à Paz Híbrida e que, portanto, não ousa romper com este paradigma, ainda que não 0 defendam incondicionalmente. Sobre o caso do Brasil no Haiti, Blanco e Guerra (2017) ilustram perfeitamente a limitação das críticas ao intervencionismo. Apesar de considerarem que a Minustah reproduz a postura de "missão civilizatória" típica do colonialismo europeu, os autores concluem seu texto clamando por uma maior democratização da missão, mas não pelo seu encerramento. A solução poderia ser encontrada dentro do intervencionismo, mediante pequenos ajustes operacionais, como a inclusão de atores da sociedade civil haitiana no processo decisório. Desta forma, com as devidas correções, este modelo poderia seguir em uso, até para operações futuras, caso supere-se "o paradigma civilizatório" da Paz Liberal (2017, p. 272)

Mais emblemática ainda é a apreciação de Moreno et. al (2012), que afirmam realizar uma abordagem "pós-colonial" da Minustah - uma reivindicação comum nos estudos da Paz Híbrida, mesmo que seja para defender a presença das forças de ocupação. Segundo esta análise (que conta entre seus autores com um militar que trabalhou no setor de inteligência logo no início da Missão $)^{5}$, os brasileiros teriam "mostrado um engajamento alternativo com a diferença", um "comportamento conciliatório" e "maneiras inovadoras" de lidar com os dilemas enfrentados (2012, p. 383-384). Tal atitude teria sido possível pelo "estabelecimento de relações mais empáticas", uma vez que, "ao trazer para campo memórias compartilhadas de sofrimento", os militares brasileiros seriam capazes de "reconhecer seus Outros (pós-coloniais) internos": esta "ambiguidade" do lugar de fala brasileiro sobre o Haiti produziria um hibridismo capaz até de "desestabilizar o imaginário civilizacional reproduzido pelo modelo da paz liberal" (2012, p. 388).

Percebe-se, assim, como tais abordagens se encaixam naquilo que pode ser entendido como Teorias de Resolução de Problemas. Ao contrário dos questionamentos que veremos a seguir, elas insistem em relançar as práticas intervencionistas sob justificativa humanitária, mesmo que seja preciso depurá-las

\footnotetext{
${ }^{5}$ Para uma autodescrição de sua participação na Minustah, como membro do Estado-Maior do general Augusto Heleno Ribeiro, ver Braga (2017).
} 
de algum elemento específico a fim de recuperar a legitimidade de uma Paz Liberal constantemente repaginada. Afastam-se de forma decisiva, portanto, do tipo de leitura feito pelas chamadas Teorias Críticas: aquelas que não estão interessadas em resolver um aspecto particular de uma dada questão, mas revelar as relações de poder envolvidas e contribuir para superá-las como um todo (COX, 1981). ${ }^{6}$ Tendo em vista que o objetivo maior deste artigo não é fazer um escrutínio das análises disponíveis, mas, especialmente, dar a conhecer opções críticas ainda pouco disseminadas na academia brasileira, optou-se por evitar uma discussão mais ampla acerca das limitações das abordagens existentes a fim de preservar espaço para a apresentação das ferramentas analíticas de diferentes Teorias Críticas. $O$ desequilíbrio, portanto, é proposital e visa, sobretudo, apresentar a literatura menos conhecida no Brasil sem distorcê-la ou estigmatizá-la como "hipercrítica", proporcionando aos leitores um contato com tais abordagens que não as desqualifique previamente e, assim, evidencie seu potencial analítico e normativo. ${ }^{7}$

\section{Economia-Política da Paz Liberal: a crítica gramsciana}

Michael Pugh é um dos autores considerados hipercríticos por Paris (2010), devido a seu engajamento sistemático na tarefa de evidenciar os elos entre o capitalismo global e o projeto da paz liberal. Em The political economy of peacebuilding (2005), ele argumenta que o intervencionismo "tem sido uma resposta à lógica do capitalismo industrial e pós-industrial" (2005, p.23) e que, portanto, nada haveria de altruísta neste tipo de humanitarismo. Pelo contrário, "o projeto liberal não apenas ignora os problemas socioeconômicos confrontados por sociedades rasgadas pela guerra", mas na realidade "agrava a vulnerabilidade de setores da população à pobreza" (2005, p.25). Além de não escutar a população local para

\footnotetext{
${ }^{6}$ Cox (1981) não é o único, muito menos o primeiro, a fazer uso do conceito de Teoria Crítica da forma como o empregamos aqui. Sua utilização deve-se a seu impacto na teorização de Relações Internacionais, mas ele próprio é tributário da discussão frankfurtiniana de Max Horkheimer (2002), que opõe "teorias críticas" às "teorias tradicionais" (2002, p.188-243). Para uma abordagem decolonial sobre teoria crítica, ver Santiago Castro-Gómez (2005, p.184).

${ }^{7}$ Por esta razão, as citações diretas foram traduzidas para o português pelo autor no intuito de facilitar sua compreensão pelo público brasileiro. Para uma revisão mais aprofundada da bibliografia que consideramos como Teorias de Resolução de Problemas frente ao tema em tela, sugerimos a leitura dos capítulos 2 e 5 da tese de doutorado deste autor, disponível em (Acesso em janeiro de 2020): https://www.maxwell.vrac.puc-rio.br/37787/37787.PDF
} 
definir os projetos de reconstrução, a presença internacional também estimularia a criação de mercados-paralelos que tornam mais difícil o acesso a bens de subsistência. No Haiti, por exemplo, criou-se um mercado altamente inflacionado para o consumo de água mineral potável após a introdução da epidemia de cólera pelos próprios soldados da ONU. Mas a maior parte da população não possuía recursos para comprar água engarrafada e continuava exposta aos riscos de contaminação devido ao preço elevado que somente os estrangeiros conseguiam arcar. Houve ganhos financeiros para quem se envolveu neste comércio, mas o custo em termos de saúde pública foi ainda mais elevado (CHERY, 2017). ${ }^{8}$

Pugh (2005) argumenta que as intervenções fazem parte de "uma ortodoxia agressivamente promovida" durante os anos 1990, centrada na abertura de mercados e privatizações em larga escala, às expensas de bens e espaços públicos (2005, p.23-24). Até mesmo os empréstimos concedidos para reconstrução seriam questionáveis, pois muitos vão com cláusulas que obrigam a compra de produtos e equipamentos nos países que fornecem 0 financiamento, impedindo 0 desenvolvimento da economia local. Sua conclusão é que a Paz Liberal está destinada a garantir a expansão da "ideologia da globalização" e do modelo de "democracia de mercado" para regiões previamente renitentes em aplicar os "imperativos mercadológicos" (2005, p.33). Para ele, sem uma superação da "agenda liberal", é de se esperar que "subjugação, em vez de emancipação, continue a ser injetada na economia-política do peacebuilding" (2005, p. 38).

Argumento similar emana da abordagem de lan Taylor. Em Liberal Peace, Liberal Imperialism: a gramscian critique (2010), ele reforça as conclusões de Pugh (2005) ao salientar que as sociedades em pós-conflito são alvos oportunos para a imposição de terapias de choque neoliberais, conforme já notado por Naomi Klein em seu famoso Doutrina de Choque: a ascensão do capitalismo de desastre (2007). Sua agenda principal, portanto, seria a facilitação de reformas em direção ao livremercado e à adoção de uma concepção liberal de democracia. Em situações de calamidade, segundo esta lógica, é mais difícil para movimentos sociais, sindicatos e

\footnotetext{
${ }^{8}$ Estimativas da própria ONU calculam 10 mil vítimas fatais decorrentes da epidemia de cólera, além de mais de 800 mil infectados (em uma população inferior a 10 milhões de habitantes). Movimentos sociais haitianos estimam os números em 30 mil e dois milhões, respectivamente. Para as cifras oficiais completas, ver reportagem recente do jornal The Guardian, disponível em (acesso em janeiro de 2020): https://www.theguardian.com/world/2019/oct/01/haiti-cholera-2010-un-us-supreme-court
} 
partidos de esquerda resistirem ao poder daquilo que Taylor (2010) identifica como uma "elite transnacional", cuja visão particular de mundo, "o neoliberalismo", é hegemonicamente apresentada como de interesse universal (2010, p.155-156). Para que isto funcione, vozes dissidentes também precisam ser silenciadas em paralelo ao bombardeamento constante de mensagens favoráveis à Paz Liberal.

O ponto central da Paz Liberal, segundo esta linha de raciocínio, seria "construir o arcabouço institucional" capaz de permitir ao setor privado "operar sua mágica em sociedades no pós-conflito" (2010, p.159). Além da análise teórica e normativa, Taylor (2010) ancora sua argumentação em alguns documentos da própria ONU. O ex-secretário geral Kofi Annan, por exemplo, perante o Fórum Econômico de Davos, em 1997, afirmava que "o capitalismo de mercado não possui nenhum grande rival ideológico" e que o elo entre as Nações Unidas e o setor privado seria "vitalmente importante", clamando, por esta razão, pelo "reforço" da parceria entre a $\mathrm{ONU}$, os governos nacionais e a "comunidade corporativa internacional". ${ }^{9}$ Taylor (2010), portanto, tem poucas dificuldades em demonstrar seu argumento, uma vez os próprios agentes à cabeça da Paz Liberal fazem o nexo entre neoliberalismo e humanitarismo interventor: sem o protagonismo do "setor privado ao redor do mundo", segundo Kofi Annan (1997), "a paz continuará frágil e a justiça social será um sonho distante" (citado por Taylor, p.158).

Novamente, o caso haitiano é paradigmático desta agenda político-normativa. O coordenador da Plataforma Haitiana de Advocacia para um Desenvolvimento Alternativo (PAPDA), Camille Chalmers, economista da Universidade do Estado do Haiti, resume a implementação da Paz Liberal em seu país em linhas congruentes com a crítica gramsciana. Para ele, as missões da ONU serviram para "instalar o neoliberalismo" e reforçar o controle estrangeiro sobre a ilha caribenha:

Depois do terremoto, as tropas internacionais se aproveitaram da situação para tomar o controle estratégico de espaços econômicos. Pretendem fazê-lo com a mineração e querem introduzir sistemas de agroexportação e também zonas francas. Tudo isso para transformar o sistema econômico haitiano e utilizar a presença das tropas da ONU, a Minustah,

${ }^{9}$ Citações traduzidas livremente do discurso de Kofi Annan (1997), cuja íntegra pode ser lida em: https://www.un.org/press/en/1997/19970131.sgsm6153.html (Acessado em agosto de 2019). 
que usaram o pretexto da crise política para instalarem-se no país (CHALMERS, 2016, s/p). ${ }^{10}$

A Minustah interferiu diretamente no resultado de eleições presidenciais no Haiti (SEITENFUS, 2016), além de sustentar no poder alguns personagens como Michel Martelly, cantor haitiano que vivia nos Estados Unidos e, posteriormente, Jovenel Möise, rico empresário exportador de bananas. Em suas gestões, avançouse em privatizações e na financeirização da economia nacional. O despojo de terras de camponeses em benefício do agronegócio e projetos extrativistas minerais foi intenso, ensejando a constituição de um movimento contra a mineração a céu aberto no país. Comunidades foram deslocadas para criação de resorts e praias exclusivas para turistas a bordo de cruzeiros de luxo. Além disto, a forte repressão aos sindicatos que lutam por melhores condições laborais nas zonas industriais do país (em sua maioria, linhas de montagem maquilladoras e do setor têxtil) facilita que as multinacionais lá instaladas continuem pagando os salários mais baixos do hemisfério, uma vez que o direito de greve não é assegurado na prática. ${ }^{11}$

\section{Biopolítica e governamentalidade: a objeção foucaultiana à Paz Liberal}

Há um importante número de pesquisadores em RI seguindo o legado de Michel Foucault e sua crítica filosófica aos modos de exercício de poder. Para esta corrente, o neoliberalismo e a Paz Liberal devem ser entendidos, sobretudo, como dispositivos de controle sobre indivíduos e populações. Mark Duffield, por exemplo, é um autor atento às práticas discursivas das intervenções humanitárias do pósGuerra Fria. Seu olhar crítico sobre conceitos como segurança humana - central para as narrativas intervencionistas contemporâneas - é crescentemente informado

\footnotetext{
${ }^{10}$ Ver a entrevista completa com o economista em: http://www.resumenlatinoamericano.org/2016/09/30/entrevista-a-camille-chalmers-en-haiti-sufrimosuna-agresion-muy-violenta-del-imperialismo/ (Acessado em agosto de 2019).

${ }^{11}$ Informações transmitidas em entrevista realizada pelo autor com Camille Chalmers em fevereiro de 2017. Tais relatos foram corroborados em entrevistas realizadas no mesmo mês com lideranças de movimentos sociais haitianos, como o Kolektif Jistis Min, além de sindicalistas ligados ao movimento político Batay Ouvriye. Para mais, conferir entrevista publicada em português com um de seus membros, disponível em (acesso em janeiro de 2020): https://mst.org.br/2007/03/12/militantehaitiano-denuncia-militarizacao-do-haiti/
} 
por leituras foucaultianas sobre o tema, o que lhe permite tratá-lo como "uma tecnologia de governança internacional" $(2005$, p.3). Isto porque haveria um giro nos objetos-referentes dos discursos na era das chamadas novas guerras: da segurança do Estado para a das pessoas; daí a noção de segurança humana. No entanto, este movimento não deveria ser celebrado como progressista ou emancipatório, uma vez que constrói discursivamente sujeitos "não-seguros", os quais, por sua vez, precisariam da intervenção externa para que sua vida coletiva seja garantida, melhorada ou tornada resiliente frente aos imprevistos e às inseguranças do mundo chamado de subdesenvolvido (DUFFIELD, 2007, p.216).

Esta prática discursiva seria uma das expressões do conhecido nexo entre desenvolvimento e segurança, que permite às grandes potências e instituições internacionais o exercício de um poder disciplinar sobre os indivíduos e de tipo biopolítico sobre as populações do Sul global. Tal constatação advém do reconhecimento de que as narrativas que alardeiam um constante estado de emergência na segurança humana exigem, como contraparte, intervenções humanitárias permanentes. Uma guerra sem fim (Unending Wars, 2007) em nome das pessoas e modos de vida que são apresentados como estando sempre em situação de risco, fragilidade e necessitados de melhorias nas áreas econômica, educacional, de saúde ou gestão pública (DUFFIELD, 2007; NOGUEIRA, 2014).

É por isto que ele questiona se, ao fim, tais mecanismos não estariam sinalizando o advento de uma "tirania biopolítica global" (2005, p. 17). Uma forma de poder atrelada a um "racismo codificado", que está na base daquilo que Duffield identifica como "paradoxo original" do liberalismo: uma filosofia política que fala em nome da liberdade, do povo e seus direitos para a cidadania doméstica, ao passo que sempre esteve disposta a aceitar formas "não-liberais" de dominação no exterior (2007, p. 225-227). A radicalidade da crítica foucaultiana à Paz Liberal também pode ser vista na apreciação de autores com Nehal Bhuta. Em Against State-Building (2008) ele situa as atuais práticas na mesma genealogia dos modos de pensamento político dos reformistas liberais do Império Britânico do século XIX e também das Teorias da Modernização do século XX. Junto com os discursos sobre boa governança e transição democrática do Novo Institucionalismo da ciência política norte-americana, tais narrativas compartilham da aspiração comum de realizar uma "engenharia de sujeitos humanos", que precisam ser tornados "objetos de 
conhecimento, medição, calibragem" e, assim, passíveis de serem "refeitos em nome do telos da ordem normativa consagrada" (2008, p.518).

Para Bhuta (2008), estamos diante de "tecnologias de intervenção política" que revelam "uma ideologia da tutela" (2008, p. 258-259). Tais discursos tendem a criar "técnicas de pensamento" que homogeneízam o espaço político e social de sociedades não-ocidentais, gerando "objetos-artefatos de saber" que precisam ser melhorados por uma intervenção externa que lhes traga maior racionalidade (entendida como universal e emanada do ocidente). A afinidade entre tais técnicas residiria, segundo sua análise, em sua epistemologia comum, contida no "movimento conceitual" de reduzir as diferentes realidades locais a "variáveis", "fatores", "tipos" ou mesmo "culturas" (2008, p.532). Esta operação epistêmica criaria as condições de possibilidade para intervenções. ${ }^{12}$

Outra contribuição importante advém dos trabalhos de John Heathershaw, que busca captar a "forma de governamentalidade" das operações de construção da paz, nas quais marcadores éticos, espaciais e temporais oscilam significativamente, mas terminam por constituir um "modo híbrido de governança hegemônica de caráter liberal-conservador-humanitário" (2008, p. 621). Assim como Duffield (2007), ele acredita que a intenção seja promover intervenções internacionais sem limites, uma vez que são lançadas a partir de uma "ordem mundial virtual" (HEATHERWHAW, 2008, p.599). Isto o faz concluir que a construção liberal da paz é "imperial", pois tenta reabilitar um grau de intervencionismo "ausente desde o declínio do colonialismo após a Segunda Guerra Mundial” (2008, p.621). No entanto, segundo Heathershaw (2008), poucos "peacebuilders" veriam a si próprios como representantes do braço armado de um poder imperial. O problema, ao contrário, seria que a maioria possui um autêntico fervor "evangélico" e genuinamente "internacionalista" na sua devoção ao trabalho humanitário-interventor, mesmo que isso termine por reproduzir a fronteira entre $E u$ e o Outro durante a tarefa de transformar os Outros naquilo que Nós (no ocidente) imaginamos ser (2008, p.603).

\footnotetext{
${ }^{12}$ Isto o leva a concluir que: "[e]stes modos de pensamento político não são apenas meras ideias ou representações que podem ser corrigidas ou ajustadas. São modos políticos de ser, que são codificados, operacionalizados e disseminados por uma variedade de circuitos: financeiros, acadêmicos, não-governamentais. Eles são, em outras palavras, a quintessência de formas de poder/saber, no sentido foucaultiano, que ativamente concebe, formata e disciplina subjetividades políticas na criação de novos modos e ordens" (Bhuta, 2008, p.521).
} 
Existe grande variedade na bibliografia de inspiração foucaultiana sobre Governamentalidade Global, conforme notado por Wendy Larner e William Walters (2009). Há autores que vêm propondo usos inovadores para este instrumental teórico, como é o caso de Costas Constantinou e Sam Opondo (2016), que refletem sobre o fenômeno da fusão entre diplomacia, defesa e desenvolvimento ("3Ds") em territórios considerados desgovernados. Tais aparatos, fusionados, representariam "uma mudança ontológica da biopolítica para a biodiplomacia" (2016, p.308). No mesmo espírito, Michael Dillon e Julian Reid (2009) propuseram o conceito de biohumanitarismo ao salientar que o papel das agências de ajuda humanitária é considerado como parte integral do próprio esforço militar nas intervenções contemporâneas. Todos, ao fim, recorrem à clássica definição de Foucault sobre o nascimento da biopolítica. ${ }^{13}$ Não é difícil, por este motivo, ver a conexão que tais autores estabelecem da biopolítica com a Paz Liberal, já que se trata de um regime discursivo que constrói suas intervenções mediante o poder de fazer a vida viver (DILLON E REID, 2009).

Embora esta vertente da crítica à Paz Liberal seja uma das mais volumosas hoje em dia, ainda existem poucos trabalhos dedicados ao caso haitiano. Por exemplo, Maíra Siman Gomes (2016) propôs uma análise da Minustah baseada em teorias pós-estruturalistas de política externa. Sua conclusão é que a entrada do Brasil na Missão teria servido principalmente para estabilizar uma determinada concepção de identidade nacional brasileira - dominante, porém instável - que estaria fragilizada em função de eventos domésticos no início dos anos 2000.

Não é difícil, no entanto, imaginar como a intervenção promovida pela Minustah possa seguir sendo analisada mediante ferramentas de inspiração pósestruturalista, em geral, ou foucaultiana, em particular. A ênfase colocada nos discursos oficiais brasileiros sobre projetos de desenvolvimento local remete diretamente às argumentações de Duffield $(2005,2007)$ sobre o nexo entre desenvolvimento e segurança. Da mesma forma, a insistência no papel desempenhado pelo Batalhão de Engenharia brasileiro no Haiti alude ao papel biohumanitário descrito por Dillon e Reid (2009), que "é exemplificado pela sua contribuição na reconstrução de infraestrutura no bojo das intervenções e conquistas

\footnotetext{
13"Pode-se dizer que o velho direito de causar a morte ou deixar viver foi substituído por um poder de causar a vida ou devolver à morte" (Foucault, 1988, p.129).
} 
liberais" (2009, p. 153). Até mesmo a intelectualidade militar pode servir de objeto para questionamentos desta natureza, uma vez que, dentre suas formulações autoelogiosas sobre o desempenho brasileiro no Haiti, encontra-se o trabalho de Barros et. al. (2013) sobre a medicina veterinária naquele país, que é justamente o exemplo dado por Constantinou e Opondo (2016) de biodiplomacia em espaços tidos como "desgovernados" (2016, p. 307).

\section{Pensamento pós-colonial: é possível descolonizar a Paz Liberal?}

Como visto, a conexão entre as atuais intervenções humanitárias e as antigas práticas dos impérios ultramarinos europeus é notada por uma série de autores críticos (e até mesmo por defensores da Paz Liberal contemporânea). ${ }^{14}$ Afinal, "não é coincidência que boa parte das atividades de peacebuilding tenha como alvo as sociedades pós-coloniais" (JABRI, 2016, p.154). Não surpreende, portanto, que representantes do chamado pensamento pós-colonial (MBEMBE, 2008) tenham se debruçado sobre o tema em questão. Ainda que retenham importantes nuanças entre $\mathrm{si}$, tais abordagens em geral enfatizam a necessidade de se olhar para a Paz Liberal a partir do ponto de vista daqueles que sofrem as intervenções. Este "reposicionamento da mirada analítica" (SABARATNAM, 2013, p. 271) seria fundamental para capturar adequadamente o poder de "forças estruturais", tanto discursivas quanto materiais, que constituem esta problemática: o "legado colonial e seu impacto continuado no presente"; e a "estrutura desigual da economia política global" (JABRI, 2016, p.154).

De acordo com Vivienne Jabri, a "multidão de práticas" englobadas sob a rubrica de peacebuilding contribui decisivamente para a constituição daquilo que chamamos de "o internacional" nos dias de hoje, como um local distinto onde a política pode ocorrer: por isto, é importante nomeá-lo de "internacional pós-colonial" (2015, p.8-9). Esta dimensão possui uma "racionalidade policialesca" que entende as ameaças à paz como resultantes da falta de governo em "estados falidos", os

\footnotetext{
${ }^{14} \mathrm{~A}$ admissão pública de Michael Ignatieff é emblemática: "A reconstrução de nações [nation-building] é o tipo de imperialismo que você tem em uma Era de Direitos Humanos, uma época em que as grandes potências acreditam, simultaneamente, no direito de pequenas nações a governarem a si próprias e no seu próprio direito de mandar no mundo" (2002, s/p.).
} 
quais precisariam das intervenções para redesenhar suas estruturas e construir uma nova arquitetura social segundo um "script" cujos autores são estrangeiros, ainda que sua implementação também dependa de atores locais $(2015$, p.10-11; 2016, p.159). Esta seria a agenda política de construção liberal da paz. Ela ressalta, ademais, que o "projeto de peacebuilding" envolve uma aspiração "pedagógica", uma vez que o treinamento das populações locais é tido como central para a construção de capacidades para o autogoverno (2015, p.14). Além de "arrogante", esta "racionalidade colonial" impediria que os resultados esperados fossem obtidos, uma vez que identifica as fontes do conflito unicamente nesta suposta incapacidade local e não como resultantes de disputas políticas reais existentes em qualquer sociedade, incluindo as pós-coloniais (2016, p.163). O "paradoxo do peacebuilding" residiria nesta despolitização aguda, que mina as chances de uma autoridade política legítima ser construída, levando à "quebra da solidariedade social e da relação direta entre cidadão e estado" (2016, p.163). Tal "desentendimento dos conflitos subjacentes" leva à adoção de "práticas mal direcionadas" fadadas ao fracasso, além de "desempoderar as comunidades locais mesmo que reivindique-se estar incluindo e empoderando-as" (2016, p.159).

No plano econômico, a Paz Liberal representaria uma "nova fase [das teorias] da modernização", que culpa as ex-colônias por seu próprio atraso, ao passo que ignora "o legado colonial de espoliações" (2016, p. 159; 163). Ao direcionar todo o "maquinário institucional do peacebuilding" em função da correção daquilo que é visto como disfuncional nas sociedades-alvo, fica-se cada vez mais distante de qualquer sucesso em promover uma "paz pós-colonial" (2016, p.165): para tanto, seria necessário ir muito além da agenda gerencial no "microcosmo" das missões em direção a uma análise profunda das estruturas jurídico, política e econômica "do internacional como uma localização distinta da política" (2015, p.16).

Outra crítica contundente pode ser encontrada nos trabalhos de Meera Sabaratnam, que se baseia mais em teorias decoloniais latino-americanas do que no pensamento pós-colonial em voga no mundo acadêmico anglo-saxão. Seu foco é revelar (e enfrentar) a colonialidade do poder (QUIJANO, 2005) envolvida nas operações da Paz Liberal e também alertar para a reminiscência de avatares de eurocentrismo em algumas críticas ao intervencionismo (SABARATNAM, 2013). Em seu estudo sobre a intervenção em Moçambique, ela identifica quatro "fatores 
estruturais" que têm suas "raízes na colonialidade": a necessidade de protagonismo dos interventores; a descartabilidade da energia e tempo das pessoas que participam dos projetos e programas implementados, que geralmente não produzem efeito real algum; o senso de direito ao privilégio (entitlement) racializado demonstrado pelos agentes estrangeiros; e, por fim, a dependência financeira que os governos locais desenvolvem em relação aos chamados doadores internacionais (SABARATNAM, 2017, p.142). Tais fatores produzem "um padrão disseminado e persistente de alienação entre os alvos da intervenção" que, segundo ela, entendem muito bem o "hiato entre aquilo que as intervenções prometem e o que elas de fato proporcionam (2017, p.135).

Ela chama atenção para o fato de que os "protocolos e práticas" humanitárias reinscrevem a diferença colonial (MIGNOLO, 2003), isto é, a noção naturalizada de uma "humanidade bifurcada" entre aqueles que praticam e os que sofrem as intervenções: soaria absurda a ideia de levar uma delegação de especialistas africanos para oferecer assistência e ensinar, por exemplo, aos funcionários públicos britânicos como fazer seu trabalho e, ainda por cima, recebendo um salário muito superior para prestar tal consultoria. Tal experimento mental mostra os limites do "universalismo" de uma "modernidade" que "em suas coordenadas históricas e epistêmicas não pode ser separada de sua colonialidade", uma vez que "não se baseia em relações morais e científicas de equivalência, mas em relações geoculturais de diferença colonial" (SABARATNAM, 2017, p. 136-137 - itálicos no original).

Após analisar as "dinâmicas de intervenção" a partir desta "matriz colonial de poder global" (2017, p.136; 142), Sabaratnam reflete sobre as chances de descolonizar as intervenções, problemática expressa já no título de seu livro. Apesar de cética quanto a esta possibilidade, ela sugere que, caso fosse possível, isto envolveria "abandonar suas premissas intelectuais centrais, seus modos de operação e suas estruturas políticas" (2017, p.142). Contudo, mesmo que uma "ampla transformação estrutural seja, em última instância, necessária”, alguns gestos iniciais poderiam ser tomados desde já: o reconhecimento da responsabilidade histórica que troque a noção de "ajuda humanitária" pela de "reparação da ferida colonial"; uma contabilização dos "custos de oportunidade" de cada suposto "beneficiário" que participa de oficinas de formação ou projetos-piloto; 
o financiamento de projetos decididos autonomamente pelas autoridades estatais "locais"; e, principalmente uma "ética de responsabilidade pós-colonial" que leve em conta as espoliações em curso e faça "os governos e públicos ocidentais pararem de reclamar para si uma autoridade moral", já que muito "roubo" e "corrupção" acontecem em áreas sob sua supervisão e controle (2017, p. 142-144).

No caso do Haiti ocupado, esta postura colonial é denunciada pela antropóloga haitiano-americana Gina Athena Ulysse, que entende sua tarefa como a de uma "acadêmica periferizada engajada no projeto de descolonizar a antropologia" (2015, xxxiii). Publicado em edição trilingue que inclui o kreyòl haitiano, seu trabalho opera uma brutal inversão da mirada analítica, focando nas práticas e discursos daqueles que dizem estar ajudando seu país, especialmente quando provenientes de homens, brancos e abastados ("white-savior industrial complex") cujo protagonismo apagaria a própria presença política dos haitianos (2015, p.xxvi). Inspirada, dentre outros, em autores como Aimé Césaire, ela apresenta uma firme atitude anticolonial, denunciando a Minustah como uma ocupação humanitária de seu país-natal, termo que toma emprestado de Gregory Fox (2008). Tal ocupação não é apenas militar, sendo também cultural e epistêmica, que traz o racismo como "código" que decifra as "complexas tensões entre classe, cor e linguagem" (2015, p.57) visíveis nos tropos que mobilizam a religiosidade vodu mediante estereótipos de exotismo misterioso ou nas insistentes identificações do Haiti como "o país mais pobre do hemisfério" (2015, p.55). Tal pobreza raramente vem acompanhada de sua origem colonial, como se fosse um fenômeno endógeno e crônico haitiano. Ecoando os alertas de Jabri $(2015,2016)$ e Sabaratnam (2017) sobre "ajuda" humanitária, ela questiona o destino dos recursos financeiros enviados ao país, que raramente chegavam ao Estado haitiano, ficando retidos por atores não-governamentais estrangeiros na "república das ONGs" (2015, p.57). ${ }^{15}$

O sociólogo haitiano Franck Seguy também critica esse papel das ONGs em seu país. Em Humanitarismo e Questão Racial no Haiti (2015), ele traz uma série de casos da época em que o país esteve sob a Minustah em que os melhores cargos foram sempre reservados para pessoal vindo de fora do país, cujos salários são muito superiores aos destinados para a mão-de-obra local: "ninguém dentre os arautos do Humanitarismo sente vergonha em construir dois mundos lado a lado.

${ }^{15}$ Estima-se que mais de 10 mil ONGs estrangeiras operem no Haiti (Seitenfus, 2016, p.319-320). 
Para eles o fausto pomposo; enquanto a abjeta miséria fica para os desabrigados haitianos" (2015, p. 146). Sua denúncia daquilo que nomeia como Internacional Comunitária vai mais além, pois seu intento seria a total recolonização do Haiti (2014), conforme o título de sua tese de doutorado.

Lançando mão de uma abordagem decolonial, ele entende as intervenções exteriores como partes do "projeto da modernidade", motivo pelo qual o clamor por modernização seria parte do problema e não das soluções (2014, p.179). Valendose das análises de Walter Mignolo, "para quem não se pode ser moderno sem ser colonial", Seguy (2014) reconhece o Haiti nesta "lógica da colonialidade" afirmando que "foi junto com a colonização e a escravidão que a modernidade chegou no Haiti (2014, p.224). Ao questionar os "fundamentos ontológicos da modernidade" (2014, p.221), sua análise crítica frontalmente o imaginário modernizante de autores como Hegel, Weber e Habermas, muito difundidos em seu país. Tais proposições invertem o frequente discurso que apregoa a existência de um caos hobbesiano no Haiti, o qual somente poderia ser resolvido via a instauração de uma ordem estatal moderna. De modo contra intuitivo e decolonial, Seguy (2014) sugere que "o Estado moderno é um sucesso no Haiti" e que "ele era imprescindível para o processo de recolonização do país depois da proclamação da independência" (2014, p. 190).

Portanto, seria preciso, segundo o autor, realizar uma "recusa da epistemologia da modernidade", pois "a retórica da modernidade trabalha mediante a imposição da salvação" (2014, p.236), propiciando, assim, as condições discursivas de possibilidade para quem se propõe a salvar ou consertar o Haiti. ${ }^{16}$ Seguy (2014) se insurge contra "a dificuldade desses intelectuais moderno-coloniaisracistas [de] admitirem que possa existir na face da terra outras perspectivas que não sejam pensadas e concebidas dentro da ontologia colonial moderna racista" (2014, p.242).

Há inúmeros exemplos que envolvem o Brasil neste regime humanitário criticado pelos autores pós e decoloniais. A constante racialização do discurso perpassa obras jornalísticas e pronunciamentos oficiais, nos quais o Haiti é identificado como A república negra, conforme indicado pelo livro de Lucas Kawaguti (2006) contendo histórias de um repórter sobre as tropas brasileiras no Haiti. O ex-

\footnotetext{
${ }^{16} \mathrm{Um}$ estudo da universidade da própria ONU, coordenado por Heine e Thompson (2011), sintomaticamente leva o título de Fixing Haiti, confirmando a tese de Seguy (2014).
} 
chanceler Celso Amorim, por sua vez, sempre destacava "afinidades de natureza étnica e cultural" para justificar "um maior envolvimento" (leia-se, intervenção) brasileira no Haiti (2006, s/p), expediente reproduzido no consulado brasileiro em Porto-Príncipe, onde o vice-cônsul enfatizou uma "irmandade africana" entre as nações, pouco antes de afirmar que os haitianos e africanos tem uma "eterna vontade de serem mimados pelo colonizador" (entrevista ao autor, fevereiro de 2017).

A racialização, portanto, vem acompanhada de uma paternalista "taxonomia do afeto" ou "economia emocional" (GROVOGUI, 2006, p.34) baseada em uma linearidade evolutiva que concebe o Outro como infantil, "anterior" e "inferior" (QUIJANO, 2005, p.238), e também foi evocada pelo policial brasileiro da Minustah entrevistado por este autor no Campo Delta, que repetiu cinco vezes em menos de uma hora que "os haitianos não estavam preparados para andar com as próprias pernas". A infantilização, portanto, é um dispositivo da racionalidade eurocêntrica e fica patente em narrativas que concebem o Haiti como um local que segue "necessitado de alguma tutela [c]omo ocorre em outras ex-colônias europeias da América", conforme afirmado em artigo pelo coronel Mendonça, ex-integrante da Minustah (2017, p. 64).

$O$ ápice desta postura colonial-racista encontrada durante $\mathrm{O}$ trabalho de campo dava-se quando o microfone era desligado, permitindo, por exemplo, que um Major gaúcho à serviço da Minustah advertisse ao autor deste artigo que não utilizasse transporte público na capital haitiana: "Vais entrar num tap-tap [microônibus] cheio de pretos fedorentos?". O mesmo oficial afirmava com ares de sabedoria: "o problema aqui é cultural, isso nunca vai mudar". Surpreendentemente, tal discurso foi reproduzido ipsis litteris no consulado brasileiro, onde o diplomata entrevistado (mesmo com o gravador ligado) não se acanhava em afirmar que o pior defeito local seriam os hábitos da "cultura haitiana", como "pedir dinheiro para quem você não conhece".

\section{A crítica feminista da militarização humanitária}


As abordagens feministas de Relações Internacionais sempre destacaram as construções de gênero feitas pelos discursos de segurança internacional como um modo de dar legitimidade a ações armadas no exterior. Autoras como Ann Tickner defendem que os "mitos de proteção" de mulheres e crianças terminam por criar as condições de possibilidade para intervenções estrangeiras (2002, p. 284). Apesar disto, é notório (e contraditório) o fato de que, nos dias de hoje, são justamente estas as categorias de pessoas as mais afetadas pela militarização levada a cabo pelas intervenções.

Os "conceitos tradicionais de masculinidade e feminilidade socialmente construídos" (2002, p.286) reforçam tais mitos. Isto vale tanto para ações abertamente descritas como guerras, mas também para aquelas que se encaixam no âmbito das operações de pacificação militarizadas. Afinal, é justamente sob a égide do paradigma da Paz Liberal que a doutrina da Responsabilidade de Proteger atinge seu paroxismo, levando consigo ao ápice destes mitos de proteção, como afirma Tarja Väyrynen em seu trabalho Gender and Peacebuilding (2010). As análises feministas dão especial atenção à figura do herói masculino, que é construído como um guerreiro justo, cuja função é salvar mulheres e crianças de um inimigo homem, em geral racializado como não-branco (TICKNER, 2002, p. 284). A crítica feminista, deste modo, muitas vezes se une ao tipo de objeção feita em termos pós-coloniais, devido à interseccionalidade das opressões.

Kimberly Hutchings (2011) ataca diretamente estas narrativas que se baseiam na construção de três personagens: a vítima, o herói e o vilão. Seu foco de análise reside nas "premissas sobre autoridade moral e agência necessárias para a ética humanitária" que se baseiam sobre "discriminações de gênero" (2011, p. 28). Por isto, é preciso entender bem o papel daquilo que é transmitido como "humano" no "humanitarismo", pois não se trata sobremaneira de um conceito inocente ou mesmo inequivocamente unitário (2011, p.34). Ela percebe que o humanitarismo é inerentemente relacional, o que significa que requer um critério para distinguir entre os seres humanos que ajudam e aqueles que são ajudados: distinções radicais entre razão e emoção; autonomia e vulnerabilidade; controle e anarquia; salvadores e vítimas. Tais dicotomias são baseadas em - ao mesmo tempo em que reforçam construções hegemônicas de gênero, uma vez que, de um lado, temos os "totalmente humanos" (conhecedores, capazes, adultos) e, de outro, os 
"residualmente humanos" (ignorantes, incapazes, infantis), ou seja, as representações arquetípicas do masculino e do feminino (2011, p. 30), como herói e vítima, respectivamente - que contrastam com o puramente "desumano", o vilão. Tais discriminações de gênero contidas no "enredo moral do humanitarismo" servem para esconder as reais causas e complexidades envolvidas em cada "emergência humanitária" mediante o emprego de "ficções políticas" carregadas de gênero que constituem o "conto de fadas humanitário" tradicional (2011, p.40-41). Despolitiza-se a situação, silencia-se sobre suas origens e termina-se sempre com a mesma necessidade de intervir, diante da narrativa apresentada, segundo a qual os homens precisam salvar as mulheres.

Cyntia Enloe, por sua vez, questiona essa invisibilidade das mulheres enquanto sujeitos nas narrativas sobre política internacional. Em seu famoso livro Bananas, Beaches and Bases, ela chama atenção para as estruturas sociais no entorno de bases militares ao redor do planeta, onde invariavelmente ocorrem "relações sexuais militarizadas" na forma de prostituição e sequestro de mulheres que vivem ou são deliberadamente transladadas para o seu entorno (2014, p.156). Além disto, os casos de assédio sexual e estupros são a regra, não a exceção, em tais ambientes, tanto para mulheres de fora das bases, quanto para as próprias militares que trabalham nas forças armadas. Em ambos os casos, a subnotificação impede uma real estimativa da amplitude do fenômeno, uma vez que nem mesmo as mulheres que fazem parte das tropas ocupantes sentem-se seguras para denunciar seus colegas de farda. Ela relata o caso de uma sargento do exército norteamericano que foi estuprada por um superior enquanto servia no Afeganistão, em 2007. Com medo de ser repreendida caso o denunciasse, ela buscou ajuda do capelão da base, que lhe disse, em troca, que "o estupro havia sido a vontade de Deus" e aconselhou-a a frequentar a igreja (2014, p.155).

Esta "política sexual" que acompanha as bases militares muitas vezes não é tratada como assunto de política internacional, o que requer uma ótica feminista para que seja corretamente apreendida (2014, p.169): a rigor, tratá-la como um "escândalo" é uma das formas de apresentar a questão como se fosse a exceção em vez da norma, uma vez que "escândalo" denota algo pouco usual quando, na realidade, trata-se de algo comum e normalizado (2014, p.157; 173). A nãoproblematização pela disciplina de Relações Internacionais de práticas que 
permanecem invisíveis sustentará sua perpetuação pelo tempo em que se continue crendo que são questões apenas de nível pessoal. Daí sua conhecida constatação de que "o pessoal é internacional" e "o internacional é pessoal" (2014, p. 343).

No Haiti ocupado pelas tropas da Minustah, esta situação foi amplamente registrada por reportagens, livros e ONGs, sendo admitida até mesmo pela própria ONU (que possui um histórico de 'escândalos' neste sentido também em outras missões, como no Congo ou Serra Leoa). ${ }^{17}$ Em 2007, um batalhão inteiro de soldados do Siri Lanka chegou a ser repatriado sumariamente, pois seus 108 membros fizeram da base em que estavam instalados um local onde eram exploradas sexualmente várias mulheres haitianas, incluindo menores de idade. ${ }^{18} \mathrm{O}$ comandante do batalhão era responsável por gerir esta rede de prostituição e abusos, realizada muitas vezes em troca de comida.

Esta prática, conforme alertado por Enloe (2014), é rotineira e, por mais que tenha sido negada por autoridades brasileiras, também envolveu militares provenientes deste país no Haiti ocupado. ${ }^{19}$ O livro de Igor Patrick (2017) relata casos a partir de entrevistas feitas com mulheres haitianas que sofreram esta violência, dentre elas uma que chegou a buscar ajuda na embaixada brasileira em Porto Príncipe, após o registro de sua denúncia ter sido negado pela Minustah. Mas o embaixador também se recusou a recebê-la, pois "estaria indiretamente validando a sua denúncia" (2017, p. 115), ilustrando novamente as engrenagens da subnotificação retratada por Enloe (2014): "Diga a ela que procure um advogado ou uma ONG", afirmara o diplomata (Patrick, 2017, p. 116).

As ONGs feministas haitianas, de fato, estão repletas de denúncias desta natureza, pois terminaram sendo um dos poucos locais de acolhida para as mulheres estupradas pelos militares da Minustah. Durante o trabalho de campo no Haiti, o autor deste artigo teve a oportunidade de entrevistar a diretora da maior ONG feminista do país, a Solidariedade entre Mulheres Haitianas (SOFA). Ela

\footnotetext{
${ }^{17}$ Para uma reportagem especial da Agência Associated Press sobre os esquemas de abuso e exploração sexual pelas tropas da ONU, conferir:

https://www.apnews.com/e6ebc331460345c5abd4f57d77f535c1 (Acessado em agosto de 2019).

${ }^{18} \mathrm{Cf}$., a respeito, reportagem da época em:

http://g1.globo.com/Noticias/Mundo/0,,MUL167598-5602,00-

SRI+LANKA+RETIRARA+SOLDADOS+DO+HAITI+POR+TEREM+RELACOES+COM+PROSTITUTA S.html (Acessado em agosto de 2019).

${ }^{19} \mathrm{Ver}$ reportagem do jornal Estado de $S$. Paulo com depoimento das vítimas em: https://internacional.estadao.com.br/noticias/geral,soldados-brasileiros-sao-acusados-de-abusossexuais-no-haiti-diz-agencia-de-noticias,70001741751 (Acesso em Janeiro de 2020).
} 
confirmou que sua entidade recebeu inúmeros casos de violência sexual cometidos por soldados da ONU, incluindo brasileiros. Por sua vez, um oficial brasileiro dentro do Campo Delta da Minustah, em Porto Príncipe, fez ecoar os alertas de Enloe (2014) ao informar (sem que houvesse sido perguntado) o preço do sexo com haitianas que viviam no entorno da base militar: "com cinco dólares você come qualquer uma aqui”. Além de demonstrar que seu comentário explicitamente indicava a relação entre exploração sexual e pobreza no âmbito de missões humanitárias, também é preciso lembrar que a ONU considera, em suas diretrizes, que qualquer contato desta natureza é considerado estupro (mesmo que aparentemente tenha sido consensual), justamente pelas disparidades de poder e riqueza entre as partes envolvidas. ${ }^{20}$

Mas não foi apenas no âmbito estritamente militar ou de funcionários civis da Missão que este tipo de situação aconteceu. Como acontece em toda intervenção, as forças multilaterais são acompanhadas de uma série de organizações sem fins lucrativos ou religiosas, que acabam sendo parte da lógica humanitária em seu conjunto. Por exemplo, a ONG britânica OXFAM recentemente admitiu que seu diretor no Haiti se envolveu em uma rede de prostituição após o terremoto de 2010. O governo haitiano chegou a cancelar a autorização para que esta entidade permanecesse em seu país. ${ }^{21}$ Por outro lado, missionários evangélicos já protagonizaram diversos casos em que orfanatos foram transformados em locais de abuso sexual e venda de menores haitianos e haitianas. ${ }^{22}$

Por tais motivos, autoras como Spike Peterson insistem que na disciplina de RI deva-se "levar a sério as questões de gênero" (1992, p.11-15), o que naturalmente inclui o subcampo de estudos de segurança internacional e, dentro

\footnotetext{
${ }^{20}$ Inúmeras questões permanecem sem resposta nestes casos. Por exemplo, quem é o responsável legal a ser processado nesta situação: o indivíduo, o país de origem ou a própria ONU? Quem pagará as despesas, como pensão alimentícia, das crianças que por ventura nasçam desta situação? De modo geral, o ônus recai exclusivamente sobre as mulheres haitianas, sem qualquer reparação material, assistência psicológica ou jurídica de parte daqueles envolvidos nas violências sexuais. Mais uma reportagem denunciando o tema surgiu recentemente, nas páginas do New York Times, que afirma: "mais de 200 mulheres relatam ter tido filhos com soldados do Brasil, Uruguai e outros países". Disponível em (acesso em janeiro de 2020):

https://www1.folha.uol.com.br/mundo/2019/12/forcas-de-paz-da-onu-no-haiti-teriam-deixadocentenas-de-filhos.shtml

${ }^{21}$ Cf., a respeito, reportagem do jornal The Guardian em (Acessado em agosto de 2019): https://www.theguardian.com/world/2018/jun/14/haiti-shuts-down-oxfam-gb-over-prostitution-scandal ${ }^{22} \mathrm{Cf}$., a respeito, reportagem da Fox News, em (Acessado em agosto de 2019): https://www.foxnews.com/us/haiti-missionary-sentenced-to-23-years-for-child-sex-abuse.
} 
dele, o tema das intervenções humanitárias da Paz Liberal. Isto não implica, para muitas autoras, necessariamente afirmar que os homens são mais belicosos, ao passo que as mulheres seriam mais pacíficas, tema que divide as feministas até hoje. Ao contrário, como afirma Mary Burguieres (1990), trata-se desmontar o imaginário que sustenta o patriarcado e o militarismo em vez de reforçá-los ao se sugerir que a guerra seria masculina e a paz feminina. Afinal, as operações de paz, como visto acima, seguem apresentando os mesmos sintomas que as operações de guerra, uma vez que são decorrentes do mesmo regime discursivo e da formação misógina de todo e qualquer soldado ao redor do mundo, sempre treinado para provar sua "hombridade" militar e evitar qualquer comportamento tido como, fraco, medroso ou, simplesmente, "feminino" (TICKNER, 2002, p. 284; SEGAL, 1987, p. 187).

\section{Conclusão}

Este apanhado de abordagens sobre a Paz Liberal a partir de instrumentos de Teoria Crítica não exaure as opções disponíveis, sendo apenas uma visão panorâmica destinada a assinalar a existência e afirmar a possibilidade de se interrogar o intervencionismo humanitário para além dos limites aos quais os paradigmas da Paz Híbrida ou da Paz Adaptativa tentam circunscrevê-lo. Esta modalidade de crítica mais radical - "hipercrítica", para Paris (2010, p. 338), ou "critica estrutural", para Gomes (2013, p. 55) - não vê tanta diferença entre operações de guerra ou de paz, quando feitas sob justificativa humanitária para as intervenções militarizadas. Por isso, ações como a invasão do Afeganistão (2001), a Guerra do Iraque (2003) ou contra a Sérvia (1998) são apreciadas pela semelhança que carregam com as operações de paz em Serra Leoa (1999), Haiti (2004) ou Congo (2010), no sentido de que tanto a guerra declarada como a paz militarizada fariam parte de um mesmo regime de governança internacional. Da mesma forma e pela mesma razão, as Teorias Críticas não enfatizam a distinção entre os tipos de operação de paz, buscando entender os tradicionais conceitos de peacemaking, peacekeeping, peacebuilding, nation-building, state-building como variações sobre um mesmo tema de fundo, ou seja, o projeto da Paz Liberal. 
Beneficiando-se da trilha analítica aberta pela teorização crítica, mas sem limitar-se ao que já existe, começam a surgir no Brasil (e demais latitudes ao Sul) trabalhos e práticas internacionais com potencial de enriquecer o questionamento do regime intervencionista ainda em voga. Concomitante ao recente interesse em verificar "o que o Brasil deixou pra trás no Haiti" (VICTOR, 2019), começa a despontar na academia brasileira uma teorização inovadora sobre o intervencionismo da Paz Liberal. Além de Seguy (2014; 2015), outro exemplo desta incipiente postura pode ser visto na sugestão de tratar a "Minustah como Haitianismo" (BORBA DE SÁ, 2019, p.218). Segundo esta proposta, a singularidade da atuação brasileira no Haiti insere-se numa genealogia que remonta ao processo de construção do Estado no século XIX, quando tecnologias de controle sócio-racial foram colocadas em prática para garantir o "sucesso" de um regime que garantiu a manutenção da escravidão por mais tempo que nenhum outro no hemisfério (2019, p. 254-255). Pesquisando fontes documentais como jornais, pronunciamentos parlamentares e registros policiais, percebe-se a criação de um regime de práticas discursivas em torno do Haitianismo (conceito que existiu somente no Brasil escravista imperial), que combinava técnicas de governo militarizadas com gestos aparentemente inclusivos dos grupos subalternizados, constituindo-se em um dispositivo passível de ser reativado em outras situações, como durante a intervenção da ONU no Haiti (2019, p. 154-158).

Existe, portanto, um terreno fértil sobre o qual a emergente teorização crítica brasileira sobre o intervencionismo humanitário começa a ser cultivado. E não apenas no Brasil, mas em toda parte onde já não se admite mais cair na armadilha retórico-normativa que os defensores do regime atual sempre preparam para sustentar ad aeternum as mesmas práticas: perguntar se em casos de emergência humanitária imediata, em que vidas possam ser salvas, não seria melhor endossar o intervencionismo e relegar todas as objeções a um segundo plano de preocupações. Esta pergunta, que já carrega em si uma resposta, foi sintetizada por um expoente da vertente solidarista da Escola Inglesa, Nicholas Wheeler (2002), e também foi endossada por Gomes (2013, p.72), que terminam, assim, chegando à mesma 
conclusão dos falcões humanitários, como Samantha Power, ${ }^{23}$ para quem jamais podemos ser espectadores do genocídio (2001).

No entanto, um reposicionamento da mirada analítica (SABARATNAM, 2013) nos ensina a fazer outras perguntas antes dessa, em particular questionar (i) como esta situação pôde chegar a ser o que é no momento, (ii) quem são os responsáveis, dentro e fora do país-alvo e (iii) se aqueles que contribuíram para o atual estado de coisas podem ser os mesmos que irão proporcionar verdadeiras soluções. Em suma, o que todas as Teorias Críticas sugerem é que precisamos repolitizar o debate sobre Relações Internacionais antes de tudo, uma vez que "toda teoria é para alguém e para algum propósito" (Cox, 1981, p. 128). Perguntas, em geral, são tão pouco inocentes quanto as respostas dadas de antemão, como lembra Joana Henriques em seu estudo sobre Racismo em Português (2017, p.12).

Esta postura é de grande serventia para analisar o caso do Haiti sob ocupação militarizada multilateral. Além de descolonizar o imaginário, permite que se note a existência de práticas concretas já em curso na América Latina e CARIBE, fazendo o des-cobrimento daquilo que foi encoberto pelo olhar eurocêntrico (DUSSEL, 2005). Há uma forma de ajuda humanitária, por exemplo, que não se inscreve no regime intervencionista. Venezuela e Cuba não mandaram um soldado sequer para o Haiti, recusando-se a participar de uma força militar eminentemente latino-americana, como a que foi Minustah. Mas a indiferença não foi a única alternativa ao intervencionismo. Tais países, enviaram, respectivamente, vastas quantidades de petróleo, via o convênio Petrocaribe (para o Estado haitiano, não para ONGs) desde 2005, assim como médicos e professores, demonstrando que o humanitarismo militarizado e interventor não é a única opção quando se trata de situações de crise em que a vida humana está em jogo (FAO, 2015). Tal modalidade de atuação foi especialmente salutar no caso do Haiti, onde não havia uma guerra civil em curso, mas que foi enquadrado mesmo assim no regime bélico-discursivo da Paz Liberal. Práticas não intervencionistas (e não militarizadas) como estas escapam ao regime de governança mundial hegemônico, mas podem ser descobertas e analisadas em trabalhos futuros pela teorização brasileira de RI caso superemos decisivamente as inibições atuais.

${ }^{23} \mathrm{O}$ termo foi cunhado pela própria autora-diplomata. Cf., a respeito, reportagem em: https://www.economist.com/democracy-in-america/2008/12/01/humanitarian-hawks (Acessado em agosto de 2019). 


\section{Referências bibliográficas}

ABDENUR, A.; CALL, C. A "Brazilian way"? Brazil's approach to peacebuilding. Order from Chaos - Foreign Policy in a Troubled World. Brookings Institute. Geoeconomics and global issues. Paper 5, February, 2017.

AMORIM, C. Discurso do Ministro das Relações Exteriores, Embaixador Celso Amorim, na sessão de abertura da Reunião Internacional de Alto Nível sobre o Haiti. Brasília: Ministério das Relações Exteriores, 23 de Maio de 2006.

ANAM, S. Peacebuilding: the Shift towards a Hybrid Peace Approach. Global \& Strategis, vol. 9, n. 1, p.37-48, 2015.

BARROS, R. et. al. A Medicina Veterinária Militar Brasileira em Operações de Paz: Experiências Colhidas na Missão da Organização das Nações Unidas para Estabilização do HAITI. Coleção Meira Mattos: revista das Ciências Militares - ECEME, vol. 7, n. 29, pp.121129, Maio/Agosto, 2013.

BHUTA, N. Against State-Building. Constellations, vol. 15, n. 4, p. 517-542, 2008.

BLANCO, R.; GUERRA, L. A Minustah como uma missão civilizadora: uma análise crítica da política internacional para estabilização do Haiti. Revista de Estudos Internacionais, vol. 8, n. 3, p. 259-275, 2017.

BORBA DE SÁ, M. "Haitianismo": colonialidade e biopoder no discurso político brasileiro. Tese de doutorado em Relações Internacionais, Pontifícia Universidade Católica do Rio de Janeiro, 2019.

BORBA DE SÁ, M.; SAID, M.; WANSETTO, R. Militarização Tipo Exportação: o perigo da Indústria Humanitária brasileira. Le Monde Diplomatique, 04/05/2017.

BRAGA, C. Os desafios iniciais da participação das Forças Armadas Brasileiras na MINUSTAH. In: HAMANN, E.; TEIXEIRA, C. (Orgs.). A participação do Brasil na MINUSTAH (2004-2017): percepções, lições e práticas relevantes para futuras missões. Edição especial - coletânea de artigos. Rio de Janeiro: Igarapé/CCOPAB, 2017.

BURGUIERES, M. Feminist Approaches to Peace: Another Step for Peace Studies, Millennium: Journal of International Studies, vol. 19, n,1,p.1-18,1990.

CARPENTER, C. Feminism, Nationalism and Globalism: Representations of Bosnian "War Babies" in the Western Print Media. In: SOJBERG, L.; VIA, S. (eds.). Gender, War and Militarism: feminist perspectives. Santa Barbara: Praeger, 2010.

CARVALHO, V. A música brasileira na MINUSTAH: a arte do soldado como diplomacia. In: HAMANN, E.; TEIXEIRA, C. (Orgs.). A participação do Brasil na MINUSTAH (2004-2017): percepções, lições e práticas relevantes para futuras missões. Edição especial - coletânea de artigos. Rio de Janeiro: Igarapé/CCOPAB, 2017.

CASTRO-GÓMEZ, S. Ciências sociais, violência epistêmica e a "invenção do outro". In: LANDER, E. (Org.). A colonialidade do saber: eurocentrismo e ciências sociais perspectivas latino-americanas. Buenos Aires: CLACSO, 2005.

CHERY, D. "Water for Profit: Neocolonialism as Cannibalism". Dancing with our Gods, 22/05/2017. 
CLAUHS, A. Os Impactos da Formação Multiétnica na Liderança Militar Brasileira em Missões de Paz. Coleção Meira Mattos: revista das Ciências Militares - ECEME, vol. 7, n. 29, pp.99-111, Maio/Agosto, 2013.

CONING, C. Adaptive Peacebuilding. International Affairs, Vol. 94, n.2, p.301-317, 2018.

CONSTANTINOU, C.; OPONDO, S. Engaging the 'ungoverned': The merging of diplomacy, defence and development. Cooperation and Conflict, vol. 51, n.3, p.307-324, 2016.

COX, R. Social Forces, States and World Orders: Beyond International Relations Theory. Millennium - Journal of International Studies, vol.10, n.2, p.126-155, 1981.

DILLON, M.; REID, J. The Liberal Way of War: killing to make life live. London/New York: Routledge, 2009.

DUFFIELD, M. Development, Security and Unending War: Governing the World of Peoples. Malden: Polity Press, 2007

Human Security: Linking Development and Security in an Age of Terror. In: New Interfaces between Security and Development (panel). Bonn: 11th General Conference of the EADI, 21-24 September, 2005.

DUSSEL, E. Europa, modernidade e eurocentrismo. In: LANDER, E.(Org.). A colonialidade do saber: eurocentrismo e ciências sociais - perspectivas latino-americanas. Buenos Aires: CLACSO, 2005.

ENLOE, C. Bananas, Beaches and Bases: making feminist sense of international politics. Berkley: University of California Press, 2014.

FACCHINI, J.; TOLEDO, A. Da transformação de conflitos à paz híbrida: uma análise das ideias de Paul Lederach e Roger Mac Ginty. Revista Brasileira de Estudos de Defesa, vol. 4, n. 2, p.153-174, jul./dez., 2017.

FAO - Food and Agricultural Organization of the United Nations. "Petrocaribe: 10 years of struggle against hunger and poverty". Special Publication, [S./L.: s./n.], 2015.

FOUCAULT, M. História da sexualidade I: a vontade de saber. Rio de Janeiro: Ed. Graal, 1988.

FOX, G. Humanitarian Occupation. Cambridge: Cambridge University Press, 2008.

GOMES, A. Da Paz Liberal à Virada Local: Avaliando a Literatura Crítica sobre Peacebuilding. Monções: Revista de Relações Internacionais da UFGD. Dourados, vol. 2, n.3, p.46-76, jul./dez., 2013.

GOMES, M. Analysing interventionism beyond conventional foreign policy rationales: the engagement of Brazil in the United Nations Stabilization Mission in Haiti (MINUSTAH), Cambridge Review of International Affairs, published online, 2016.

GROVOGUI, S. Beyond Eurocentrism and anarchy: memories of International order and institutions. New York: Palgrave Macmillan US, 2006.

HAMANN, E.; CEZNE, E. Brazilian Peacekeeping: Challenges and Potentials in Turbulent Landscapes at Home and Internationally. PRIO Policy Brief, n.22, 2016. 
HEATHERSHAW, J. Unpacking the Liberal Peace: The Dividing and Merging of Peacebuilding Discourses. Millennium: Journal of International Studies. Vol. 36, .n 3, p. 597622, 2008.

HEINE, J.; THOMPSON, A. Fixing Haiti: MINUSTAH and beyond. Tokyo/New York/Paris: United Nations University Press, 2011.

HENRIQUES, J. Racismo em português: O lado esquecido do colonialismo. 1 ed. Rio de Janeiro: Tinta da China, 2017.

HIRST, M. Aspectos conceituais e práticos da atuação do Brasil em cooperação sul-sul: os casos de Haiti, Bolívia e Guiné Bissau. Texto para Discussão, n.1687. Rio de Janeiro: IPEA, Janeiro de 2012.

HORKHEIMER, M. Critical Theory: Selected Essays. New York: Continuum International Publishing Group, 2002.

HUTCHINGS, K. Gendered Humanitarianism: reconsidering the ethics of war. In: Sylvester, C. (ed.). Experiencing War. London/New York: Routledge, 2011.

IGNATIEFF, M. Nation-Building Lite. New York Times, July 28th, 2002.

JABRI, V. Peacebuilding, the local and the international: a colonial or a postcolonial rationality?. Peacebuilding, vol.1, n.1, p.3-16, 2013.

. Post-colonialism: a post-colonial approach to peacebuilding. In: RICHMOND, O. et al. (orgs.). The Palgrave Handbook of Disciplinary and Regional Approaches to Peacebuilding. London: Palgrave-Macmillan, 2016.

KALIL, M.; NAPOLEÃO, T. Stabilization as securitization of Peacebuilding? The experience of Brazil and MINUSTAH in Haiti. Brasiliana - Journal of Brazilian Studies, vol. 3, n. 2, p.87112, March, 2015.

KAWAGUTI, L. A República Negra: Histórias de um repórter sobre as tropas brasileiras no Haiti. Rio de Janeiro: Ed. Globo, 2006.

KENKEL, K. Interests, Identity and Brazilian Peacekeeping Policy. Perspective of the World Review, vol. 3, n.2, p.9-36, 2011.

KLEIN, N. The Shock Doctrine: the rise of disaster capitalism. London: Penguin Books, 2007.

LARNER, W.; WALTERS, W. Global Governmentality: Governing international spaces. London and New York: Routledge, 2004.

LULA DA SILVA, L. I. Não vamos nos esquecer do Haiti. El País, Opinião-Tribuna, 25/02/2014.

MAC GINTY, R. International Peacebuilding and Local Resistance: hybrid forms of peace. London: Palgrave Macmillan, 2011.

MAC GINTY, R.; RICHMOND, O. The fallacy of constructing hybrid political orders: a reappraisal of the hybrid turn in peacebuilding. International Peacekeeping, vol. 23, n. 2, p.121, 2015. 
MASON, A.; WHEELER, N. Realist objections to humanitarian intervention. In: BARRY, H. Ethical dimensions of global change. London: Palgrave-Macmillan, 1996.

MBEMBE, A. What is post-colonial thinking? Eurozine, 09/01/2008.

MENDONÇA, M. Brasil no Haiti, um caso de sucesso: uma análise da missão brasileira no Haiti. In: HAMANN, E.; TEIXEIRA, C. (Orgs.). A participação do Brasil na MINUSTAH (20042017): percepções, lições e práticas relevantes para futuras missões. Edição especial coletânea de artigos. Rio de Janeiro: Igarapé/CCOPAB, 2017.

MITCHELL, A.; RICHMOND, O. Hybrid forms of peace: from everyday agency to postliberalism. London: Palgrave Macmillan, 2012.

MIGNOLO, W. Histórias locais/Projetos Globais: colonialidade, saberes subalternos e pensamento liminar. Belo Horizonte: Editora UFMG, 2003.

MORENO, M.; Braga, C.; Gomes, M. Trapped Between Many Worlds: A Post-colonial Perspective on the UN Mission in Haiti (MINUSTAH). International Peacekeeping, vol. 19, n. 3, p. 377-392, 2012.

NASSER, F. Projeção de Poder e Solidariedade na Estratégia Diplomática de Participação Brasileira em Operações de Paz da Organização das Nações Unidas. In: KENKEL, K.; MORAES, R. (Orgs.). O Brasil e as operações de paz em um mundo globalizado: entre a tradição e a inovação. Brasília: IPEA, 2012.

NOGUEIRA, J. From Failed States to Fragile cities: Redefining spaces of humanitarian practice. Third World Quarterly, vol. 38, n. 7, p. 1437-1453, February, 2017.

PARIS, R. Broadening the Study of Peace Operations. International Studies Review, vol. 2, n. 3, p. 27-44, Autumn, 2000.

. Saving Liberal Peacebuilding. Review of International Studies. vol. 36, n. 2, p. 337-365, April, 2010.

PATRICK, I. Aquilo que resta de nós: um pedido de socorro de haitianas estupradas por soldados da ONU. Belo Horizonte: Editora Páginas, 2017.

PETERSON, S. (ed.). Gendered states: feminist (re)visions of international relations theory. Boulder: Lynne Rienner, 1992.

POWER, S. Bystanders to genocide: Why the United States Let the Rwandan Tragedy Happen. Atlantic Monthly, published online, September 2001.

PUGH, M. The political economy of peacebuilding: a critical theory perspective. International Journal of Peace Studies, vol. 10, n. 2,p.23-42, Autumn/Winter, 2005.

QUIJANO, A. Colonialidade do poder, eurocentrismo e América Latina. In: LANDER, E. (Org.). A colonialidade do saber: eurocentrismo e ciências sociais - perspectivas latinoamericanas. Buenos Aires: CLACSO, 2005.

SABARATNAM, M. Avatars of Eurocentrism in the critique of the liberal peace. Security Dialogue, vol. 44, n. 3, p. 259-278, 2013. 
. Decolonising intervention: international state-building in Mozambique. London/New York: Rowman \& Littlefield, 2017.

SEGAL, L. Is the future female? Troubled thoughts on contemporary feminism. London: Virago, 1987.

SEGUY, F. A catástrofe de janeiro de 2010, a "Internacional Comunitária" e a recolonização do Haiti. Campinas, 2014, 398p. Tese de Doutorado - Universidade Estadual de Campinas, Instituto de Filosofia e Ciências Humanas. Orientador: Ricardo Antunes. jan./jun. 2015.

Humanitarismo e questão racial no Haiti. Lutas Sociais, vol.19 n.34, p.143-157,

SEITENFUS, R. Elementos para uma diplomacia solidária: a crise haitiana e os desafios da ordem internacional contemporânea. Carta Internacional, vol. 1, n.1, p.5-12, Março, 2006.

. Reconstruir Haití: entre la esperanza y el tridente imperial. Santo Domingo: CLACSO/Fundación Juan Bosch, 2016.

SOUZA NETO, D. O Brasil, o Haiti e a MINUSTAH. In: KENKEL, K.; MORAES, R. (Orgs.). O Brasil e as operações de paz em um mundo globalizado: entre a tradição e a inovação. Brasília: IPEA, 2012.

TAYLOR, I. Liberal Peace, Liberal Imperialism: a Gramscian critique. In: RICHMOND, O. (Org.). Palgrave advances in peacebuilding: critical developments and approaches. London: Palgrave Macmillan, 2010.

TICKNER, A. Feminist perspectives on International Relations. In: CARLSNAES, S. et. al. (eds). Handbook of International Relations. London: Sage, 2002.

ULYSSE, G. Why Haiti Needs New Narratives: A Post-Quake Chronicle. Trilingual Edition. Middletown, Connecticut: Wesleyan University Press, 2015.

VALLER FILHO, W. O Brasil e a Crise Haitiana: a cooperação técnica como instrumento de solidariedade e de ação diplomática. Brasília: FUNAG, 2007.

VÄRYNEN, T. Gender and Peacebuilding. In: RICHMOND, O. (ed.). Palgrave advances in peacebuilding: critical developments and approaches. London: Palgrave Macmillan, 2010.

VIANA, S. A Minustah e a participação brasileira. Revista Senso Comum, n.1, Dossiê Temático, p.22-37, 2009.

VICTOR, F. Terra Desolada: o que o Brasil deixou pra trás no Haiti. Revista Piauí, ed. 155, ago/2019.

WHEELER, N. Saving Strangers: Human Intervention in International Society. New York: OUP, 2002. 